\title{
The History of Hydrocarbon Analyses: Whence Has Forensic Geochemical Hydrocarbon Fingerprinting Come
}

\author{
Michael J. Wade ${ }^{*}$, Dennis Stainken ${ }^{2}$ \\ ${ }^{1}$ Wade Research, Inc., Marshfield, USA \\ ${ }^{2}$ Princeton-Somerset Group, Inc., Hillsborough, USA \\ Email: *mjwade@waderesearch.com,prinsomgrp@aol.com
}

Received 18 January 2016; accepted 23 February 2016; published 26 February 2016

Copyright (C) 2016 by authors and Scientific Research Publishing Inc.

This work is licensed under the Creative Commons Attribution International License (CC BY). http://creativecommons.org/licenses/by/4.0/

(c) (i) Open Access

\section{Abstract}

The current techniques used in forensic geochemical hydrocarbon fingerprinting have their genesis along with the evolution of gas chromatography as it applies to hydrocarbon research. In the United States, a small group of government and academic chemists and marine scientists pioneered the use of gas chromatography in the identification of both natural and petroleum-derived hydrocarbons. Natural products were a primary focus until the research direction was altered somewhat by marine oil spills, accidents releasing crude oil and refined petroleum products to the world's coastal marine environment, giving rise to concerns regarding biogeochemical impacts. Application of oil spill research continued from that point so that the geochemical research begun in the late 1960s and early 1970s now forms a major component of investigations of petroleum releases both in the aquatic and terrestrial environments. As the capabilities for the identification of individual hydrocarbons in a variety of petroleum products improved with basic advances in chromatographic technology, new applied sciences in forensic geochemical hydrocarbon fingerprinting have emerged. While in the beginning the identification of bulk petroleum products received primary emphasis, current techniques are now capable of distinguishing among a variety of potential sources including those derived from natural processes, undetected individual releases, chronic releases and obvious catastrophic releases. However, a review of the techniques employed in the late 1960s and early 1970s will show that the basic approaches pioneered at that time are still in use today, albeit with a higher level, with concomitant advances in chromatographic technology as the questions grow in complexity.

\section{Keywords}

Hydrocarbon Fingerprinting, Forensic Geochemistry, Gas Chromatography

\footnotetext{
${ }^{*}$ Corresponding author.
}

How to cite this paper: Wade, M.J. and Stainken, D. (2016) The History of Hydrocarbon Analyses: Whence Has Forensic Geochemical Hydrocarbon Fingerprinting Come. Journal of Environmental Protection, 7, 303-311. 


\section{Introduction}

While it might be tempting to attribute the evolution of hydrocarbon analytical techniques that existed previously into today's modern petroleum spill fingerprinting approaches to the increase in environmental awareness born in the late 1960s brought on by the publication of Rachel Carson's Silent Spring in 1962 [1], to do so would pay short shrift to the powerful influence the research community holds on the subject. True, Silent Spring, which had been serialized in the New Yorker before being published as a standalone work by Houghton Mifflin, grabbed governmental attention and, ultimately, the creation of the U.S. Environmental Protection Agency. Already, in the 1960s there were established government, industry and academic research organizations pursuing research in hydrocarbons in natural systems. Further, the development of the world's petroleum exploration and production industry played a major role in such interests. So, multiple forces can be viewed as effective here.

During the 1960s there were a series of oceanic and inland oil spills and oil pollution incidents that were well publicized. One of the most famous was the Torrey Canyon. The Torrey Canyon spill in March 1967 stimulated research on the physical behavior of oil in seawater and use of dispersants [2]. An International Conference concerning water pollution by oil was held in Scotland in 1970, with the proceeding published in 1971 [3]. Ref. [4] discussed aspects of petroleum analysis and observed that throughout the response and subsequent evaluation of oil spills, the weathering of oil was recognized as causing considerable changes in its properties. There was a need for a rapid technique for determining the type of oil that could be used for comparative purposes and evaluating possible spill sources. Gas chromatography (GC) was recommended, citing a procedure outlined in [5]. A detailed examination of the sample could include gravity, wax content, asphaltenes, and normal paraffin distribution, vanadium, nickel and sulfur content. Analytical approaches also could include the use of chromatograms and infrared spectra using a "chemical library" of known oils. Other comparisons could include chromatographic (paper or thin layer) and UV spectroscopy. It was noted that no single technique or analytical scheme was applicable to all types of oil pollutants. For weathered oils in coastal and estuarine environments, GC techniques were recommended. In addition, tar balls and oil slicks from unknown sources and bilge washings, a common annoyance on beaches, had not been studied.

\subsection{The Evolution of the U.S. Environmental Protection Agency Research}

In June 1948, the Division of Water Supply and Pollution Control was established within the U.S. Public Health Service (U.S. PHS) to administer the Water Pollution Control Act. In 1956, Congress passed the first Federal Water Pollution Act. The Act strengthened the U.S. PHS enforcement authority, increased water quality research, and initiated the wastewater construction grants program. In October 1965, the Water Quality Act of 1965 assigned its functions to the newly established Federal Water Pollution Control Administration. It was renamed the Federal Water Quality Administration by the Water Quality Improvement Act of 1970. Increasing public concerns in the U.S. over environmental issues eventually culminated in the formation of the U.S. Environmental Protection Agency (EPA) on December 2, 1970.

The mission of the newly-established EPA was to: establish and enforce environmental protection standards; conduct environmental research; provide assistance to others in combating environmental pollution; assist the Council on Environmental Quality in developing and recommending to the President new policies for environmental protection. One of the primary goals of the EPA was to provide real enforcement against polluters. In creating the EPA, the U.S. Government aggregated multiple existing governmental agencies to make the new agency. The Department of the Interior contributed Federal Water Quality Administration. The EPA received selected pesticide research responsibilities from the Department of Health, Education and Welfare, gained control over tolerance levels of pesticides from the Food and Drug Administration and the Department of Agriculture gave up selected functions regarding pesticide registration. The EPA gained control of air pollution regulations from the National Air Pollution Control Administration. Additionally, the EPA received offices from the bureaus of Water Hygiene and Solid Waste Management. Responsibilities for radiation criteria and standards were transferred from the Atomic Energy Commission, along with parts of the Bureau of Radiological Health and the Federal Radiation Council were also transferred to the EPA.

Established research scientists and, in fact, entire laboratories, were transferred to the nascent environmental agency. During 1971, the Regional Offices and the EPA complex came into being. It was recognized from the beginning that there would be a strong need for research to identify problems, what should be controlled and 
how, establish standard and reliable analytical procedures, and establish an enforcement capability. Such recognition led to the creation of the Office of Research and Development with various locations across the country. EPA's research program was established using EPA laboratories as well as contract research to industry and academia.

\subsection{Concomitant Research Evolution within Industry}

The basis for separation sciences had evolved from work in the 1940s concerned with what at the time was termed partition chromatography [6], the development of which was recognized in 1952 with the awarding of a joint Nobel Prize in Chemistry to A.J.P. Martin and R.L.M. Synge. Early research continued under their guidance in the 1950s with the development of chromatography using packed column separation evaluating liquid phases for separation of light hydrocarbons. In 1957, the first capillary column chromatogram ever was obtained as a photograph of an oscilloscope output (personal communication, Dr. H. McNair, 2015). In 1958, Professor Dr. A.I.M. Keulemans established the First Chair, Instrumental Methods of Analysis, Eindhoven, Netherlands having worked previously at Royal Dutch Shell. In 1959, a new chromatographic laboratory in a Technical University was set up in Holland and guest professors included Nobel Laureate A.J.M. Martin, as well as Dr. Marcel Golay, D. Desty, Dr. R.P.W. Scott, Dr. James Lovelock and students H. McNair and C. Cramers. Work involved manufacturing and application of capillary column gas chromatography technology. In the early 1960s, high resolution gas chromatography in basic chemical research was well underway [7].

In the petroleum industry, understanding the "fundamental nature of petroleum, its origin, and its behavior" [8] became critical parts of its resource development and economic exploitation. However, within the petroleum industry the development of company proprietary analytical techniques to facilitate the study of petroleum in the earth's crust did not extended to the environmental analytical techniques that gave rise to the hydrocarbon fingerprinting techniques used today. In fact, it is fair to say that today's forensic geochemical fingerprinting analytical methods evolved along a more tortuous route.

\subsection{Advancement of Oil Pollution Research in Academic Institutions}

By the 1960s and early 1970s there were established academic research programs at various marine educational institutions in the United States. Such institutions included Woods Hole Oceanographic Institution (WHOI), University of Rhode Island, Scripps Oceanographic Institute, Texas A\&M University, University of Washington and others. Central to these programs were established chemists focusing on petroleum geochemistry, natural product chemistry, and the study of pollution sources to the coastal and world oceans. Academic programs at such institutions gave rise to scientists who successfully drove the evolution of petroleum research into what we see as today's forensic geochemical studies and hydrocarbon fingerprinting techniques.

\subsection{Coalescence}

At some point, therefore, industry, government and academic research interests were all poised to become important forces in the pursuit of research regarding the effects of petroleum releases into the environment. Coupled with and central to these sometimes synergistic and sometimes competing interests was the evolution of analytical techniques such as gas chromatography (GC) and combined gas chromatography/mass spectrometry (GC/MS). Moreover, the rise to prominence of computer technology cannot be overlooked. As analytical chemistry techniques evolved to produce more information and lower detection limits on an increasing number of individual hydrocarbon analytes, use of less costly, widely available computer power became essential to sorting out important subtleties in the chemical data.

Today, what finally is underway is nothing less than the evolution of a new aspect of forensics sciences applied to the study of the who, what, when, where and sometimes why of petroleum contamination events in the ecosystem, guided by what is now termed the forensic geochemist. Forensic geochemistry is evolving rapidly, driven by both emerging improvements in analytical chemistry as well as new and better understanding of how to process, analyze and in the end understand chemical data. But the ultimate end use of the forensic investigation's work product by definition has to be aimed at the legal arena, an area where formalized debate on pro and con issues presents new challenges to the scientist. It must be remembered that forensic uses of chemical data are fundamentally different than academic discussion of research results. 
Therefore, it is worth noting and preserving the process of evolution that petroleum research has undergone. So, the purpose of this paper is to consolidate the issues and events that came to cause the evolution of forensic petroleum geochemistry, thereby preserving some of the prominent information going forward.

\section{Evolution of Chemical Methods Applied to Petroleum Geochemistry}

The field of gas chromatography as a science has to be viewed as a relative latecomer because infrared and ultraviolet techniques are older and more established in analytical chemistry. As governmental and academic institutions began to grapple with what analytical approaches to use in the analysis of petroleum in environmental samples, there were different proponents of potential candidate chemical methods.

\subsection{The U.S. EPA Oil Spill Program}

The U.S. EPA program was developed into several components. The FWQA and development of the NPDES permitting program needed continued analytical input to establish procedures for permitting municipal and industrial discharges. It was recognized that discharge effluents most definitely included oils. The continued spills of oils from accidents, disasters and intentional discharges, needed analytical procedures and control technology. This was part of the mission of the Oil \& Hazardous Materials Spills Branch in Edison, NJ. Analytical research also continued for various national programs in Air, Water, and Wastes, in the Environmental and Support Laboratory (EMSL) in Cincinnati. During the 1970s, much of the analytical methods development for the NPDES program and Safe Drinking Water Program and others was conducted in and through EMSL Cincinnati, which culminated initially in the codification of analytical methods in CFR 136 for the NPDES program. In the NPDES program, GC/MS was elected as an analytical approach of choice for effluents because of its ability to identify and quantify the specific chemicals listed in the "Priority Pollutant" list. Because of the complex composition of oils, a GC chromatographic approach and chromatograms was eventually favored for fingerprinting for eventual enforcement purposes.

\subsubsection{The Oil \& Hazardous Materials Spills Branch (OHMSB)}

The Oil \& Hazardous Material Spills Branch (OHMSB) was established in 1971 at the former US Army Raritan Depot in Edison, NJ. The laboratory was built inside a former warehouse building, along with Regions 2's Laboratory and Regional Offices. OHMSB also maintained a large experimental oil spill tank at part of the Navy complex in Earle, NJ, and a smaller experimental spill tank at the rear of the warehouse. The Branch conducted an aggressive contract and in-house research program into means to prevent and treat releases of oils and hazardous materials. Indeed, it was at this EPA laboratory that initial forays into what would later be termed hydrocarbon fingerprinting began.

Shortly after establishing the program, the Water Quality Improvement Act of 1972 and the development and passage of the Clean Water Act of 1977 authorized the Federal Government to take emergency response action when oils and specially designated hazardous substances are discharged into navigable waters. Passage of RCRA in 1976 further addressed chemicals and hazardous wastes necessitating both analytical methods and control technology.

Focusing on the analytical needs for petroleum analysis within the OHMSB programs, the following objectives needed to be addressed:

- The physical behavior of the oils when spilled into water, seawater, sediments, and soils.

- The effects of physical treatment of the oil by weathering or dispersants.

- The biodegradation of the oils and identification of degradation residues.

- The forensic issues of the oil: identifying whose oil was released and what fraction came from where.

- The analytical methods needed to address:

$\diamond$ what fraction of oil to analyze.

$\diamond$ a dependable and reproducible analytical method.

$\diamond$ establish reliable and reproducible QA practices around the method.

$\diamond$ the ease, practicality and rapidity of the method.

\subsubsection{OHMSB Oil Analytical Outputs}

During the period 1971-1978, the focus of analytical development was the evaluation of a means to quantify, 
and identify, oil pollution in water, primarily using IR techniques, gas chromatography, and fluorescence spectroscopy. During this period, the EPA Environmental \& Support Laboratory in Cincinnati published a monthly "Analytical Control Newsletter" in which numerous analytical and quality control observations and findings of methods and method improvements by OHMSB staff could be found.

An earlier report of an oil tagging approach had been issued in 1970 [9] for identifying the source of oil pollution. The methods suggested included passive and active tagging. The passive tagging (trace metals, sulfur isotope ratios, paper chromatography) was not recommended because the tags could evaporate, dissolve or mingle with other contaminants.

Contract research was a means of further evaluating methodology. A report was published in 1973 evaluating oil pollution source identification [10]. This study developed a method for identification of sources of oil comparing stable chemical indices present in unweathered and weathered oil. The method used GC/MS for analysis of aromatic hydrocarbons and naphthenes; GC was used for n-paraffins, X-ray for total sulfur, and Kjeldahl total nitrogen. Several compound indices were found to be stable which could distinguish between oils with a high degree of statistical confidence. Another report [11] evaluated the use of carbon and sulfur isotope composition, sulfur, nitrogen, vanadium and nickel content of oil and use of GC for identification of crude oils.

A contract for development of GC to correlate and identify oils culminated in a publication "Correlation of oils and oil products by gas chromatography" by [12]. This publication presented the chromatograms of different oils for comparative purposes. It established a detailed method for fingerprinting weathered and unweathered oils and included an appendix containing chromatograms of 52 samples of crude and distillate oils. A routine method of sampling, sample extraction, analysis and interpretation was provided for monitoring, enforcement and damage assessment purposes. The method as published used a surface coated open tubular (SCOT column coated with OV-101). Use of capillary columns was addressed but in the end SCOT columns were chosen for use based on their ability to provide increased capacity and durability, with a flow resistance that was low and reproducible. In chromatogram interpretation, the unresolved area under the peaks was termed an "unresolved envelope" and a "background of unresolved substances", terms which did not gain wide acceptance in the chemical community. Instead, that feature of gas chromatograms became known as the "Unresolved Complex Mixture" or UCM, a term that was originated by [12]. It was UCM that came to be the default term in gas chromatography for decades thereafter [14] and is still widely used today. The analysis procedure and later variants were used in OHMSB analytical tasks. Within the OHMSB lab, a file of chromatograms of crude and distillate oils was maintained for identification purposes. It was noted there were many ways to alter oil chromatograms based on the types of oil, crude or distillate, manner of extraction and by which solvent, drying techniques, and GC instrumentation techniques such as column bleed, septum bleed, use of auto-attenuation, detector and detector maintenance, gain settings on the instrument, carrier gas flow, etc. Oil hydrocarbon analytical research in the OHMSB lab was also conducted using various support coatings and capillary columns such as 6' SS columns packed with 8\% Dexsil on Chromosorb W [15]-[17] coupled with other techniques such as infrared and fluorescence spectroscopy and GC/MS.

\subsubsection{Research within OHMSB}

The OHMSB and chemists were involved in many inter- and intra-agency work groups in establishing and validating analytical methods for oils and oil products, national spill responses, and ASTM Committees. Research areas within OHMSB led to the publication of findings in the use of several analytical areas including fluorescence spectroscopy [18]-[20], infrared spectrophotometry [21]-[23] and emulsion preparation, gas chromatography [24]-[26] and reviews of analytical procedures and techniques [27].

\subsubsection{The United States Coast Guard}

The U.S. Coast Guard had been given responsibility for control and response to oil pollution incidents in coastal and inland waters and by 1977 had established a manual "Oil Spill Identification System." With budget shifts and national needs changing during this time frame, the mission of OHMSB was further focused on issues involving hazardous chemicals and wastes. This led to creation of the Environmental Response Team, field implementation of the technology that the OHMSB had developed, and a Mobil Analytical Lab. The U.S. EPA Region II's analytical laboratory capabilities were eventually transferred to the U.S. Coast Guard. The Oil Identification System (OIS) was established during the mid-1970s at the Coast Guard Research and Development Center, New London, Connecticut. In 1978, the Central Oil Identification Laboratory (COIL) was established to 
implement the OIS. In 1988, COIL was renamed the Marine Safety Laboratories (MSL), and in 1996 Marine Safety Laboratories became Marine Safety Laboratory. It remains today the central analytical facility for marine oil spills for the U.S. Coast Guard.

\subsection{The Role of Marine Petroleum Transport Accidents}

In the academic institutions, research on hydrocarbons in natural products was a primary focus until the research direction was altered somewhat by marine accidents releasing petroleum products to the United States coastal marine environment. Multiple researchers were engaged in this type of work. Initial concerns on oil pollution were generated by the Torrey Canyon incident, but it might be argued by some that no single marine pollution incident is more illustrative of this particular effect than what has come to be called the West Falmouth Oil Spill. In 1969, the barge Florida grounded near West Falmouth, Buzzards Bay MA, and released about 180,000 gal of No. 2 fuel oil. WHOI scientists in Falmouth, Massachusetts, which was located very near the spill site in Wild Harbor, completed benchmark studies on this release [28] [29] plus numerous others. Chemical analyses at that time most likely were performed using packed-column gas chromatography. While things have changed in the analytical laboratory since the late 1960s and early 1970s, over three decades later in the early 2000s, hydrocarbons that were characteristic of degraded No. 2 fuel oil could still be found in the Wild Harbor salt marsh sediments [30].

Before and since the Florida oil spill, multiple major and minor oil spills occurred (see the summary [31]). However, considering circumstances, spilling fuel oil proximal to the WHOI research laboratories probably was not the best idea one could have ever had; undoubtedly, it was not a deliberate decision to spill oil at West Falmouth. The proximity of the discharge to the WHOI offered unique opportunities for study and the advancement of petroleum forensics.

Certainly research continued without the "aid" of oil spills However, looking back, it seems that with each major petroleum spill there has been a jump in the technical responses to the geochemical demands being placed upon scientists by the petroleum industry, government agencies and attorneys. Perhaps one such event is the 1989 Alaskan Oil Spill. As the Exxon Valdez left Valdez, Alaska with a full load of North Slope Crude Oil (NSCO), through a variety of known and unknown circumstances, according to the Exxon Valdez Oil Spill Trustee Council, the ship ran aground on Bligh Reef at 12:04 am March 24, 1989. Subsequently, approximately 11 million gallons or 257,000 barrels of NSCO were released into Prince William Sound. Subsequent migration of the released crude oil impacted significant portions of Alaskan coastal waters. To say that a significant effort went into scientific studies on the oil spill would be to state the obvious [32].

However, at the time, analytical methods were being developed which would take advantage of combined gas chromatography/mass spectrometry using capillary column chromatography. Shortly after the 1989 Alaskan Oil Spill occurred, investigators realized that the existing EPA analytical methods based upon fixed analyte lists, TPH measurements, or IR measurements would not begin to address the questions that were being and would also be asked in a legal setting. Consequently, they set about to redefine the available GC/MS analytical methods, focusing specifically on NSCO [33]. The analytical methods to be used were more or less set but analyte lists had to be expanded and refocused to a more petroleum product based list and the focus on crude oil became singular for research on this particular oil spill. Continued refinement of analytical approaches has continued as issues have been raised and addressed by investigators. Applications of the analytical methods employed to address legal issues from the 1989 Alaskan Oil Spill have proliferated to numerous laboratories throughout the world [34]-[36].

As a consequence to the increased level of legal issues surrounding release of petroleum products to the environment [37], new work was completed that centered on volatile gasoline range organics (GRO). Development of analytical approach to deal with volatile organic compounds (VOCs) focused on the five hydrocarbon classes found in gasoline: paraffins, isoparaffins, aromatics, naphthenics and olefins [38]. The analyses, which had been known in the petroleum industry as PONA or PIANO, were adapted to the U.S. EPA 8260 analytical method using combined capillary column gas chromatography/mass spectrometry and the approach has proliferated to numerous laboratories throughout the world. The PIANO analytical approach continues to offer new opportunities for research on sourcing releases of GRO to the environment [39].

On April 20, 2010, the largest oil spill in U.S. waters occurred in the Gulf of Mexico. The Deepwater Horizon Macondo oil well drilling platform exploded and sank with loss of life. For approximately three months, an un- 
confined release of crude oil continued, until it was capped in July 2010. Subsequently, the Deepwater Horizon event has been studied by existing techniques as well as newly developed two-dimensional gas chromatography (GC X GC). The technique exhibits numerous advantages including improved peak resolution, lower costs, faster data turnarounds, as well as enumeration of entire classes of hydrocarbons without overlap. GC X GC had already been applied to the tracking of petroleum weathering in yet another oil spill in Buzzards Bay, MA [40]. And while it cannot be said that the Deepwater Horizon oil spill brought out the development of comprehensive GC X GC for analyzing petroleum hydrocarbons in environmental samples [41], it can certainly be said that the resulting research funding loosened by private industry and the U.S. Government spurred its proliferation. Again, driven by the demands of a marine oil spill, new applications of a higher-level geochemistry were brought out by forensics demands to yet more precise and focused analytical methods. Since the Deepwater Horizon oil spill, GC X GC has proliferated into a wider academic and governmental community. Continued expansion of GC X GC into the commercial laboratory business has started, but slowly, and is severely limited at this point in time. Complicating the matter is the continued development of GC X GC approaches, proving once again that nothing is static in the forensic geochemical arena [14]. It remains to be seen whether GC X GC, regardless of whatever approaches are taken to modify particular analytical methods, becomes the de facto analytical method for petroleum organics regardless of matrix. However, one thing is clear. Once the analytical genie has been let out of the research bottle, changes occur.

\section{Conclusion}

The evolution to the current state of the art on forensic geochemical hydrocarbon fingerprinting has not been a smooth progression or for that matter a planned program. It can be more accurately characterized as a demand and opportunity driven series of events. The analytical methods for petroleum hydrocarbon fingerprinting that are currently being used by academic, governmental, private industry and contract laboratories vary. Changes in the available analytical techniques will continue as well. Development of forensic hydrocarbon geochemical approaches cannot be attributed to any single event or group, but, in fact, reflect the best that science has to offer in the building of knowledge upon the groundbreaking work of others who have contributed to its inevitable progression.

\section{Acknowledgements}

This paper was initially presented at the 2015 International Network of Environmental Forensics (INEF) conference held in Toronto, Ontario, Canada, in August 2015. In a work such as this, there is some likelihood that one group or anther may have been unintentionally given short shrift or omitted. Such was not the intent of this work. The authors appreciate the multiple INEF meeting attendees who responded to our requests for any additional insights into development of gas chromatography in the forensic geochemical community that subsequently were used in this paper. It is through such assistance that we acknowledge our deep gratitude for the personal observations of Dr. Harold M. McNair, Professor Emeritus of Chemistry, Virginia Polytechnic Institute and State University for his insights into his work in the chemistry laboratory of Nobel Laureate A.J.P. Martin. We also thank two anonymous reviewers for their time and efforts on our behalf.

\section{References}

[1] Carson, R. (1962) Silent Spring. Anniversary Edition, Houghton Mifflin Harcourt Publishing Company, New York.

[2] Smith, J.E. (1970) “Torrey Canyon” Pollution and Marine Life. New Edition, Cambridge University Press, Cambridge.

[3] Hepple, P. (1971) Water Pollution by Oil. Proceedings of a Seminar Held at Aviemore, Scotland, May 1970, Hepple, P., Ed., The Institute of Petroleum, Elsevier.

[4] Duckworth, D.F. (1971) Aspects of Petroleum Pollutant Analysis. In: Water Pollution by Oil, Elsevier Publishing Company, 165-185.

[5] Ramsdale, S.J. and Wilkinson, R.E. (1968) Identification of Petroleum Sources of Beach Pollution by Gas-Liquid Chromatography. Journal of the Institute of Petroleum, 54, 326.

[6] Martin, A.J.P. (1952) The Development of Partition Chromatography. Nobel Lecture, 12 December 1952.

[7] Desty, D.H. and Goldup, A. (1960) Gas Chromatography. In: Scott, R.P.W., Ed., Butterworths, London.

[8] Hunt, J.M. (1979) Petroleum Geochemistry and Geology. W.H. Freeman and Company, San Francisco. 
[9] FWPCA (1070) Oil Tagging System Study. Federal Water Pollution Control Administration, Water Pollution Control Research Series, 15080DJ05/70.

[10] Lieberman, M. (1973) Oil Pollution Source Identification. EPA-R2-73-102.

[11] Miller, J.W. (1973) A Multi-Parameter Oil Pollution Source Identification System. EPA-R2-73-221.

[12] Zafiiou, O., Blumer, M., Meyers, J. and Stainken, D. (1977) Correlation of Oils and Oil Products by Gas Chromatography. EPA-600/2-77-163.

[13] Farrington, J.W. and Quinn, J.G. (1973) Petroleum Hydrocarbons in Narragansett Bay I: Survey of Hydrocarbons in Sediments and Clams (Mercenaria mercenaria). Estuarine and Coastal Marine Science, 1, 71-79. http://dx.doi.org/10.1016/0302-3524(73)90059-5

[14] Farrington, J.W. and Quinn, J.G. (2015) “Unresolved Complex Mixture” (UCM): A Brief History of the Term and Moving Beyond It. Marine Pollution Bulletin, 96, 29-31. http://dx.doi.org/10.1016/j.marpolbul.2015.04.039

[15] Stainken, D. (1975) Preliminary Observations on the Mode of Accumulation of No. 2 Fuel Oil by the Soft Shell Clam, Mya arenaria. Proceedings of the 1975 Conference on Prevention \& Control of Oil Pollution, San Francisco, 25-27 March 1975, 463-468. http://dx.doi.org/10.7901/2169-3358-1975-1-463

[16] Stainken, D. (1976) The Accumulation and Depuration of No. 2 Fuel Oil by the Soft Shell Clam, Mya arenaria. Proceedings of Symposium, Fate \& Effects of Petroleum Hydrocarbons in Marine Organisms and Ecosystems, Seattle, 10-12 November 1976, 313-322.

[17] Stainken, D. (1979) Occurrence of Extractable Hydrocarbons from Raritan Bay Sediment. Bulletin of the New Jersey Academy of Science, 24, 6-11.

[18] Frank, U. (1975) Identification of Petroleum Oils by Fluorescence Spectroscopy. Proceedings of the 1975 Conference on Prevention \& Control of Oil Pollution, San Francisco, 25-27 March 1975, 87-101.

[19] Frank, U. and Gruenfeld, M. (1977) Determination of Petroleum Oils in Sediments by Fluorescence Spectroscopy. Proceedings of the 1977 Pittsburgh Conference on Analytical Chemistry and Applied Spectroscopy, Cleveland, 28 February-4 March 1977.

[20] Frank, U. (1978) A Review of Fluorescence Spectroscopic Methods for Oil Spill Source Identification. Toxicological \& Environmental Chemistry Reviews, 2, 163-185. http://dx.doi.org/10.1080/02772247809356924

[21] Gruenfeld, M. (1973) Extraction of Dispersed Oils from Water for Quantitative Analysis by Infrared Spectrophotometry. Environmental Science \& Technology, 7, 636-639. http://dx.doi.org/10.1021/es60079a012

[22] Gruenfeld, M. (1975) Quantitative Analysis of Petroleum Oil Pollutants by Infrared Spectrophotometry. In: Water Quality Parameters, ASTM, STP 573, 290-308. http://dx.doi.org/10.1520/STP39018S

[23] Gruenfeld, M. and Frederick, R. (1977) The Ultrasonic Dispersion, Source Identification, and Quantitative Analysis of Petroleum Oils in Water. Rapports et Proces-verbaux des Reunions. Conseil International pour l’Exploration de la Mer, 33-38.

[24] Gruenfeld, M. (1973) Identification of Oil Pollutants: A Review of Some Recent Methods. Proceedings of the 1973 Conference on Prevention and Control of Oil Spills, Washington DC, 13-15 March 1973, 179-193. http://dx.doi.org/10.7901/2169-3358-1973-1-179

[25] Gruenfeld, M. and Frank, U. (1977) A Review of Some Commonly Used Parameters for the Determination of Oil Pollution. Proceedings of the 1977 Oil Spill Conference, New Orleans, 8-10 March 1977.

[26] Frank, U., Stainken, D. and Gruenfeld, M. (1979) Methods for the Source Identification and Quantification of Oil Pollution. Proceedings of the 1979 Oil Spill Conference (Prevention, Behavior, Control, Cleanup), Los Angeles, 19-22 March 1979, 323-331.

[27] Tanacredi, J.T. (1977) Petroleum Hydrocarbons from Effluents: Detection in Marine Environment. Journal of the Water Pollution Control Federation, 49, 216-226.

[28] Blumer, M., Souza, G. and Sass, J. (1970) Hydrocarbon Pollution of Edible Shellfish by an Oil Spill. Marine Biology, 5, 195-202. http://dx.doi.org/10.1007/BF00346906

[29] Blumer, M., Sanders, H.L., Grassle, J.F. and Hampson, G.R. (1971) A Small Oil Spill. Environment, 13, 2-12. http://dx.doi.org/10.1080/00139157.1971.9930568

[30] Peacock, E.E., Nelson, R.K., Solow, A.R., Warren, J.D., Baker, J.L. and Reddy, C.M. (2005) The West Falmouth Oil Spill: $\sim 100 \mathrm{Kg}$ of Oil Found to Persist Decades Later. Environmental Forensics, 6, 273-281. http://dx.doi.org/10.1080/15275920500194480

[31] Farrington, J.W. (2013) Oil Pollution in the Marine Environment I: Inputs, Big Spills, Small Spills, and Dribbles. Environment Science and Policy for Sustainable Development, 55, 3-13.

[32] Wells, P.G., Butler, J.N. and Hughes, J.S. (1995) Exxon Valdez Oil Spill: Fate and Effects in Alaskan Waters, 
STP1219. ASTM International, West Conshohocken, 956. http://dx.doi.org/10.1520/STP1219-EB

[33] Sauer, T.C. and Boehm, P.D. (1991) The Use of Defensible Analytical Chemical Measurements for Oil Spill Natural Resource Damage Assessments. Proceedings of the 1991 International Oil Spill Conference, San Diego, 4-7 March 1991, 363-369. http://dx.doi.org/10.7901/2169-3358-1991-1-363

[34] Wang, Z., Fingas, M., Yang, C. and Christensen, J.H. (2006) Chapter 16: Crude Oil and Refined Product Fingerprinting: Principles. In: Morrison, R.D. and Murphy, B.L., Eds., Environmental Forensics: Contaminant Specific Guide, AP Elsevier, Amsterdam, 340-407.

[35] Wang, Z. and Christensen, L.H. (2006) Chapter 17: Crude Oil and Refined Product Fingerprinting: Applications. In: Morrison, R.D. and Murphy, B.L., Eds., Environmental Forensics: Contaminant Specific Guide, AP Elsevier, Amsterdam, 410-464.

[36] Yunker, M.B., McLaughlin, F.A., Fowler, M.G. and Fowler, B.R. (2014) Source Apportionment of the Hydrocarbon Background in Sediment from Hecate Strait, a Pristine Sea on the West Coast of British Columbia, Canada. Organic Geochemistry, 76, 235-258. http://dx.doi.org/10.1016/j.orggeochem.2014.08.010

[37] Kaplan, I.R., Galperin, Y., Alimi, H., Lee, R.P. and Liu, S. (1996) Patterns of Chemical Changes During Environmental Alteration of Hydrocarbon Fuels. Ground Water Monitoring and Remediation, 16, 113-124. http://dx.doi.org/10.1111/j.1745-6592.1996.tb01178.x

[38] Uhler, R.M., Healey, E.M., McCarthy, K.J., Uhler, A.D. and Stout, S.A. (2002) Molecular Fingerprinting of Gasoline by a Modified Gas Chromatography/Mass Spectrometry Method. International Journal of the Environment, Analytical Chemistry, 83, 1-20. http://dx.doi.org/10.1080/0306731031000104218

[39] Wade, M., Johnson, J. and Furrer, U.B. (2015) Modeling Petroleum Hydrocarbon Degradation. Part I. Gasoline Statistics and Pattern Assemblage. Proceedings of the National Environmental Monitoring Conference, Forensic Chemistry Session, Chicago, 13-17 July 2015, Unpublished.

[40] Nelson, R.K., Kile, B.M., Plata, D.L., Sylva, S.P., Xu, Li, Reddy, C.M., Gaines, R.B., Frysinger, G.S. and Reichenbach, S.E. (2006) Tracking the Weathering of an Oil Spill with Comprehensive Two-Dimensional Gas Chromatography. Environmental Forensics, 7, 33-44. http://dx.doi.org/10.1080/15275920500506758

[41] Frysinger, G.S., Gaines, R.B. and Reddy, C.M. (2002) GC X GC: A New Analytical Tool for Environmental Forensics. Environmental Forensics, 3, 27-34. http://dx.doi.org/10.1080/713848318 